Research Article

\title{
Risanto's Formulas is more Accurate in Determining Estimated Fetal Weight Based on Maternal Fundal Height
}

\author{
Rumus Risanto lebih akurat dalam Menentukan Taksiran \\ Berat Janin Berdasarkan Tinggi Fundus Uterus Ibu
}

\author{
Hanifah I Titisari, Risanto Siswosudarmo \\ Department of Obstetrics and Gynecology \\ Faculty of Medicine University of Gadjah Mada/ \\ Dr. Sardjito Hospital \\ Yogyakarta
}

\begin{abstract}
Objectives: To compare the accuracy of Johnson's and Risanto's formulas in determining estimated fetal weight based on maternal fundal height (FH).

Methods: This was a cross sectional study, consisting of 655 pregnant women from Dr. Sardjito Hospital and affiliated hospital sat 3742 weeks of gestation. Fundal height was measured from the symphisis to the top of uterine fundus, using inverted unelastic flexible tape. EFW based on Johnson's and Risanto's formulas were compared with the actualbirth weight. Wilcox on analysis was used for statistical analysis.
\end{abstract}

Results: Mean EFW of Johnson's formula was $3136 \pm 392.2$ grams and EFW of Risanto's formula was $3056 \pm 322.5$ grams and mean actual birth weight was $3021 \pm 341.1$ grams. The mean difference between EFW of Johnson's formula and the actual birth weight was $156.1 \pm 107.3$ grams, and mean difference between EFW of Risanto's formula and the actual birth weight was $100.8 \pm 86.1$ grams. Those two differences was statistically significant $(\mathrm{p}=0.001)$.

Conclusion: This study showed that Risanto's formula was more accurate than Johnson's in predicting birth weight based on the maternal's fundal height.

[Indones J Obstet Gynecol 2013; 1-3: 149-51]

Keywords: actual birth weight, fundal height, Johnson's formula, Risanto's formula

\begin{abstract}
Abstrak
Tujuan: Membandingkan akurasi rumus Risanto dan rumus Johnson dalam menentukan TBJ.

Metode: Studi potong lintang dengan mengukur TFU pada kehamilan 37-42 minggu di kamar bersalin RS Dr. Sardjito dan RS Jejaring. Sebanyak 655 ibu hamil yang memenuhi kriteria kelayakan dimasukkan dalam penelitian ini. Taksiran berat janin dihitung berdasarkan rumus John-son dan rumus Risanto. Berat lahir ditimbang dengan menggunakan timbangan yang sama. Selisih antara berat lahir dengan TBJ Johnson dibandingkan dengan selisih berat lahir dengan TBJ Risanto. Uji Wilcoxon digunakan untuk menilai kemaknaan perbedaan selisih mean TBJ Johson dan selisih mean TBJ Risanto.
\end{abstract}

Hasil: Rata-rata TBJ Johnson adalah $3136 \pm 392,2$ gram dan rata-rata TBI Risanto 3056 $\pm 322,5$ gram dan rata-rata berat lahir adalah 3021 $\pm 341,1$ gram. Rata-rata selisih TBJ Johnson (selisih antara berat lahir dengan TBJ Johnson) adalah 156,1 \pm 107,3 gram sedangkan rata-rata selisih TBJ Risanto (selisih antara berat lahir dengan TBJ Risanto) adalah 100,8 $\pm 86,1$ gram, yang secara statistik perbedaan tersebut bermakna $(p=0,000)$.

Kesimpulan: Menunjukkan bahwa TBJ rumus Risanto lebih akurat dibanding TBJ rumus Johnson.

[Maj Obstet Ginekol Indones 2013; 1-3: 149-51]

Kata kunci: berat bayi lahir, rumus Johnson, rumus Risanto, tinggi fundus uterus

Correspondence: Risanto Siswosudarmo, Department of Obstetrics and Gynecology Faculty of Medicine University of Gajah Mada, Yogyakarta. Telephone: 08122969622, Email: h.risanto@yahoo.com

\section{INTRODUCTION}

Large or small birth weight infants might give rise to a serious problem to the neonates and their following development. Estimating accurate birth weight is important as mode of delivery may be different. Appropriate mode of delivery based on baby's size and birth weight could be reducing the poor effect of the pregnancy outcome especially for the baby. ${ }^{1}$

Fundal height has been proven to be correlated with pregnancy age and infant weight. Based on the Johnson's formula, Johnson EFW (JEFW) is cal- culated as follows: JEFW $=(\mathrm{FH}-\mathrm{n}) \mathrm{X} 155$, where EFW is in gram, FH in $\mathrm{cm}, \mathrm{n}=12$ if the fetal head is unengaged, and $n=11$ if the fetal head is engaged. ${ }^{2}$ The fundal height, however, is influenced by some factors such as maternal size, parity, fetal sex and ethnic. The Johnson formulas has been used so widely although it is based on western women.

In 1995 the new formula was developed by Siswosudarmo to estimate the infant birth weight based on maternal fundal height. Based on 560 maternal fundal height meausurement of pregnant women in the Province of Yogyakarta, Siswosudarmo found the 
formula to estimate infant birth weight. The formula is then called the Risanto's formula for estimating fetal weight (REFW), the equation of which was as follows: $\mathrm{Y}=126.7 \mathrm{X}-931.5$ where $\mathrm{Y}$ was EFW in grams, $\mathrm{X}$ was maternal fundal height in $\mathrm{cm}$ and 931.5 was the constanta. ${ }^{3}$

The aim of the present study is to compare the accuracy of Risanto's and Johnson's formulas in predicting infant birth weight in full-term pregnancy by measuring maternal fundal height.

\section{METHOD}

This was a cross sectional study conducted at Dr. Sardjito Hospital and 16 affiliated hospital in Central Jawa which might represent Malay race. All pregnant women meeting the inclusion criteria such as at 37 to 42 week gestational age, singleton baby, cephalic presentation, alive fetus and during the latent phase of labor were included. Mothers with uncertain gestational age, polihydramnion, and fetal anomalies were excluded.

Fundal height measurement was carried out by the Resident in charge with the following ways: Mother was in supine position with both hips and knees joints flexed. In case of full bladder, she was asked to void. Fundal height was measured during no contraction using flexible non-elastic tape (sewing tape) from the symphisis pubis to the top of the uterine fundus. If the uterus was slanting, an assistant was asked to fix the uterus in the midline. Measurement was done twice with the inversed tape to avoid bias, during the first stage of labor. If during the first 24 hours patients didn't give birth, then the new measurement was done. The baby was weighed during the first hours after delivery using the same baby scale after calibrated. Data were recorded using the provided forms.

\section{RESULTS}

A total of 655 pregnant mothers meeting the inclusion criteria were recruited. Their characteristics were shown in Table 1.
Table 1. Characteristics of Study Subjects.

\begin{tabular}{|c|c|c|}
\hline Characteristics & n & $\%$ \\
\hline $\begin{array}{l}\text { Age (years) } \\
\qquad<20 \\
-20-30 \\
\cdot>30\end{array}$ & $\begin{array}{r}56 \\
388 \\
11\end{array}$ & $\begin{array}{r}8.6 \\
59.2 \\
32.2\end{array}$ \\
\hline $\begin{array}{l}\text { Paritay } \\
\text { - Primiparous } \\
\text { - Multiparous }\end{array}$ & $\begin{array}{l}326 \\
329\end{array}$ & $\begin{array}{l}49.8 \\
50.2\end{array}$ \\
\hline $\begin{aligned} \text { Gestational age (we } \\
\text { - } 37-40 \\
\text { - }>40\end{aligned}$ & $\begin{array}{l}513 \\
142\end{array}$ & $\begin{array}{l}73.3 \\
21.7\end{array}$ \\
\hline $\begin{array}{l}\text { Body mass index (B) } \\
\text { - Normal } \\
\text { - High }\end{array}$ & $\begin{array}{l}283 \\
372\end{array}$ & $\begin{array}{l}43.2 \\
56.8\end{array}$ \\
\hline $\begin{array}{l}\text { Social-Economic } \\
\text { - High } \\
\text { - Middles } \\
\text { - Low }\end{array}$ & $\begin{array}{r}14 \\
51 \\
590 \\
\end{array}$ & $\begin{array}{r}2.1 \\
7.8 \\
90.1\end{array}$ \\
\hline
\end{tabular}

Based on the measurement of maternal fundal height, the JEFW, REFW and the actual birth weight were seen in the following table.

Table 2. The Central Tendencies of Actual Birth Weight, Johnson EFW, and Risanto EFW ( $\mathrm{n}=655)$

\begin{tabular}{lcccc}
\hline \hline Fetal Weight (gram) & Minimum & Maximum & Mean & SD \\
\hline Actual Birth Weight & 2050 & 4250 & 3021.6 & 341.1 \\
Johnson's EFW & 2015 & 4185 & 3136.4 & 392.2 \\
Risanto's EFW & 2171 & 3917 & 3056.2 & 322,5 \\
\hline \hline
\end{tabular}

Table 2 showed that the mean estimated fetal weight by Risanto's formula (3056 grams) seemed to be closer to the mean actual birth weight (3021 grams) compared to that of Johnson (3136 grams). The Risanto's estimated fetal weight had an excess of 35 grams while that of Johnson was 115 grams. To further analyse, the two means were compared using paired t-test and the result was seen in the following table.

This table showed that the mean Risanto was smaller that the mean Johnson signifying that the

Table 3. Comparison between $\triangle$ Johnson* $^{*}$ and $\triangle$ Risanto*

\begin{tabular}{lcccccc}
\hline & Mean & \multirow{2}{*}{ SD } & \multirow{2}{*}{$\Delta$ Mean } & \multicolumn{2}{c}{ 95\% CI } & \multirow{2}{*}{ p Value } \\
\cline { 5 - 7 } & & & & Lower Limit & Upper Limit & \\
\hline$\triangle$ Risanto & 100.87 & 86.19 & -55.29 & -61.65 & -48.93 & 0.00 \\
$\triangle$ Johnson & 156.17 & 107.37 & & & & \\
\hline \hline
\end{tabular}

*) $\triangle$ Johnson is calculated by actual birth weight - JEFW in grams

F) $\triangle$ Risanto is calculated by actual birth weight - REFW in grams 
accuracy of Risanto's formula was better than that of Johnson and it was statistically significant. The mean difference was 55.29 grams, which might be debat able weather it was clinically significant or not.

\section{DISCUSSION}

Many methods were used to estimate fetal weight, because no direct measurement was available. The convensional methods was palpation of the maternal abdomen. It varied widely because of it was influenced by maternal characteristics such as thickness of the abdomin wall, obesity and maternal height. ${ }^{4}$ Fundal height, there fore had the better sensitivity than maternal palpation, maternalheight and weight, and middle upper arm circumference. $^{5}$

The more recent method which was widely used to estimate fetal weight was using ultrasound examination. A study involving 190 subjects to compare the accuracy of abdominal palpation, Johnson's formula and ultrasound examination to estimate infant birth weight was done. The result showed that there were a significant correlation between birth weight and the variables mentioned above. ${ }^{6}$ Another study done in Thailand showed that EFW using Johnson for mulagave an excessive weight 227.17 gram (95\% CI 205.91-244.83). ${ }^{7}$ In our recent study the Johnson estimated fetal weight had an excess of 115 grams while Risanto estimated fetal weight had an excess smaller namely 35 grams (Table 2).

A similar study was done in Ehtiopia, a low resource country, comparing the Johnson formula and abdominal palpation. Results showed that for babies weighing between 2500 to 3999 grams, abdominal palpation method was more precise than Johnson formula. About 68\% of Johnson estimated fetal weight was higher than the actual birthweight. For babies weighing less than 2500 grams both abdominal palpation and Johnson formula methods were more than the actual birth weight. ${ }^{8}$

An equation to predict birth weight based on symphysis fundal height (SFH) was done by Buchmann dan Tlale. ${ }^{9}$ In their study, the derivation study $(\mathrm{n}=504)$, birth weight was predicted by the equation: birth weight in $\mathrm{g}=301+78$ (SFH in $\mathrm{cm}$ ).
This was transformed to the simplified formula: birth weight in $\mathrm{g}=100$ ([SFH in $\mathrm{cm}]-5$ ). Using this formula for the data set, $68.1 \%$ of birth weight estimates were correct to within $10 \%$ of the birth weight. For prediction of birth weight $=4000 \mathrm{~g}$, an SFH measurement of $40 \mathrm{~cm}$ had a sensitivity of $82 \%$ and a specificity of $80 \%$. In the validation study $(\mathrm{n}=294)$, the derived simplified formula gave $65.0 \%$ of estimates correct to within $10 \%$ of the birth weight. The predictive values of the $40 \mathrm{~cm}$ SFH cut-off were similar to those in the derivation study.

\section{CONCLUSION}

This study had shown that Risanto's formula for estimating birth weight based on maternal fundal height was more accurate than Johnson's formula.

\section{REFERENCES}

1. Etikan I, Caglar M. Prediction methods for babies birth weight using linear and nonlinear regression analysis. Technol Health Care, 2005; 13: 131-5.

2. Pernoll ML. Hand book of Obstetrics and Gynecology. $10^{\text {th }}$ ed, Singapore: The McGraw Hill Medical Publishing Division, 2001: 117

3. Siswosudarmo HR. Deteksi Bayi Berat Lahir Rendah pada Kehamilan Aterm dengan Pengukuran Tinggi Fundus. Berkala Epidemiologi Klinik \& Biostatika Indonesia, 1995; 1 (20): 78-84.

4. Mongelli M, Gardosi J. Symphysis-fundus height and pregnancy characteristics in ultrasound-dated pregnancies. J Obstet Gynecol, 1999; 94: 591-4.

5. Walraven G, Mkanje R, Van Roosmalen J, Van Dongen P, Van Asten H, Dolmans W. 'Single pre-delivery symphysis-fundal height measurement as a predictor of birth weight and multiple pregnancy'. Br J Obstet Gynaecol, 1995; 102: 525-9.

6. Khani S, Ahmad-Shirvani M, Mohseni-Bandpei MA, Mohammadpour-Tahmtan RA. Comparison of abdominal palpation, Johnson's technique and ultrasound in the estimation of fetal weight in Northern Iran. Midwifery 2011; 27(1): 99-103.

7. Numprasert W. A Study In Johnson's Formula: Fundal Height Measurement for Estimation of Birth Weight, Assumption University Journal, 2004; 8(1): 15-20.

8. Balete W, Gaym A. Clinical estimation of fetal weight in low resource setting: comparison of Johnson's formula and the palpation method. Ethio Med J, 2008; 46(1): 37-46.

9. Buchmann E. Tlale K. A simple clinical formula for predicting fetal weight in labour at term - derivation and validation. South Africa Med J, 2009; 99: 457-60 